

\section{DISCLAIMER}

This report was prepared as an account of work sponsored by an agency of the United States Government. Neither the United States Government nor any agency Thereof, nor any of their employees, makes any warranty, express or implied, or assumes any legal liability or responsibility for the accuracy, completeness, or usefulness of any information, apparatus, product, or process disclosed, or represents that its use would not infringe privately owned rights. Reference herein to any specific commercial product, process, or service by trade name, trademark, manufacturer, or otherwise does not necessarily constitute or imply its endorsement, recommendation, or favoring by the United States Government or any agency thereof. The views and opinions of authors expressed herein do not necessarily state or reflect those of the United States Government or any agency thereof. 


\section{DISCLAIMER}

Portions of this document may be illegible in electronic image products. Images are produced from the best available original document. 


\title{
Development and Evaluation of DOP Generators for Special Uses
}

\author{
Robert L. Mielke
}

Issued: June 18, 1976

\section{NOTICE}

This report was prepared as an account of work sponsored by the United States Government. Neither the United States nor the United States Energy Research and Development Administration, nor any of their employees, nor any of their contractors, subcontractors, or their employees, makes any warranty, express or implied, or assumes any legal liability or responsibility for the accuracy, com. pleteness or usefulness of any information, apparatus, product or process disclosod. or represents that its use would not infringe privately owned rights.

PRINTED IN THE UNITED STATES OF AMERICA

Available from

National Technical Information Service

U. S. Department of Commerce

5285 Port Roval Road

Springfield, Virginia 22161

Price: Printed Copy $\$ 400 ;$ Microfiche $\$ 2.25$

$$
3.50
$$

\section{MONSANTO RESEARCH CORPORATION}

A Subsidiary of Monsanto Company

\section{mOUND IABORATORY}

Miamisburg, Ohio

45342

operated for

\section{UNITED STATES ENERGY RESEARCH AND DEVELOPMENT ADNINISTRATION}

U. S. Government Contract No. E-33-1-GEN-53 


\section{TABLE OF CONTENTS}

Page

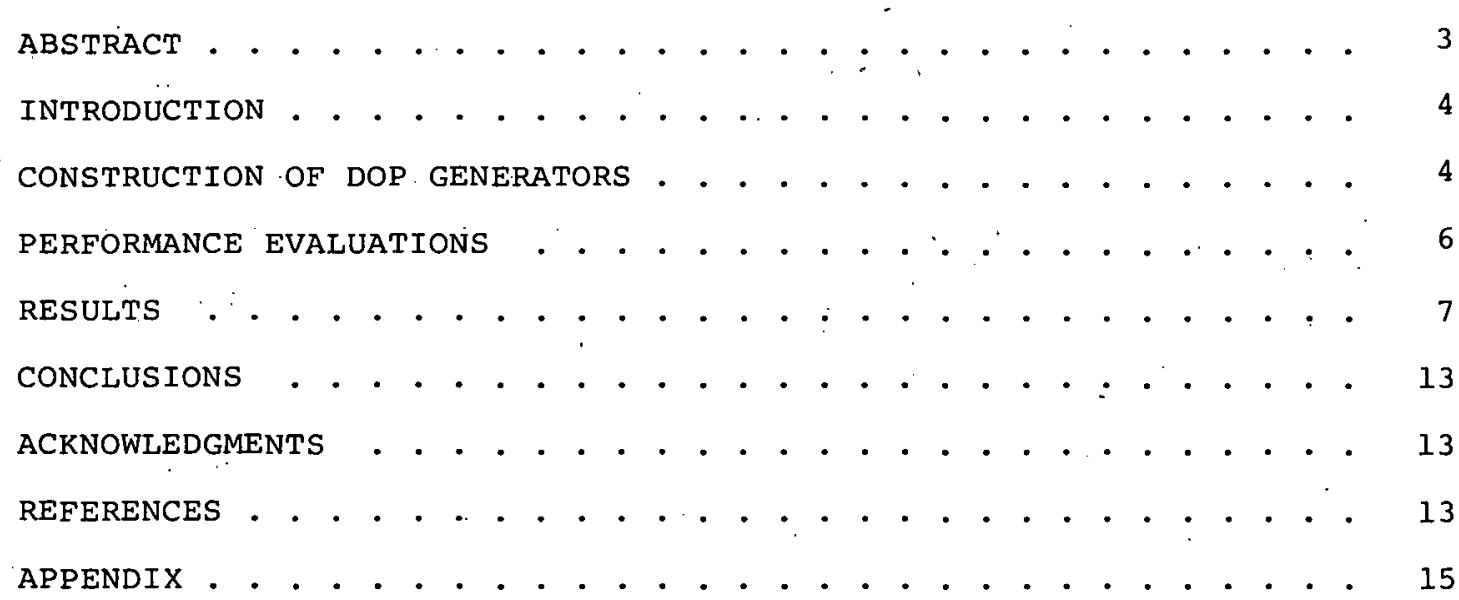


The Environmental Standards Group at Mound Laboratory uses "cold" DOP generators to produce background aerosol concentration for testing HEPA filters in clean-room operations. Two simple, portable; airoperated aerósol generators were built and tested to determine their performance.

The results show the particle size distribution is in the 0.3 to 0.8 $\mu \mathrm{m}$ range and that $1 / 4$ or $3 / 8$ in. i.d. tubing to the nozzles should be used. 


\section{INTRODUCTION}

Clean room calibration procedures' require the total scan test of HEPA (High Efficiency Particulate Air) filters using DOP (dioctyl-phthalate) aerosol. There are. two methods to generate this DOP smoke concentration, hot and cold. (See Appendix.) The Environmental Standards Group at Mound Laboratory uses the cold generation method. for this type of testing. Although commercial DOP generators are available; they do not entirely meet the special needs of the Environmental Standards Group. ' Two DOP generators were built and tested for particle size range and smoke concentration, and data were tabulated to determine their performance.

\section{CONSTRUCTION OF DOP GENERATORS}

The basic DOP generator design was taken from Sandia Process standard 9956015,

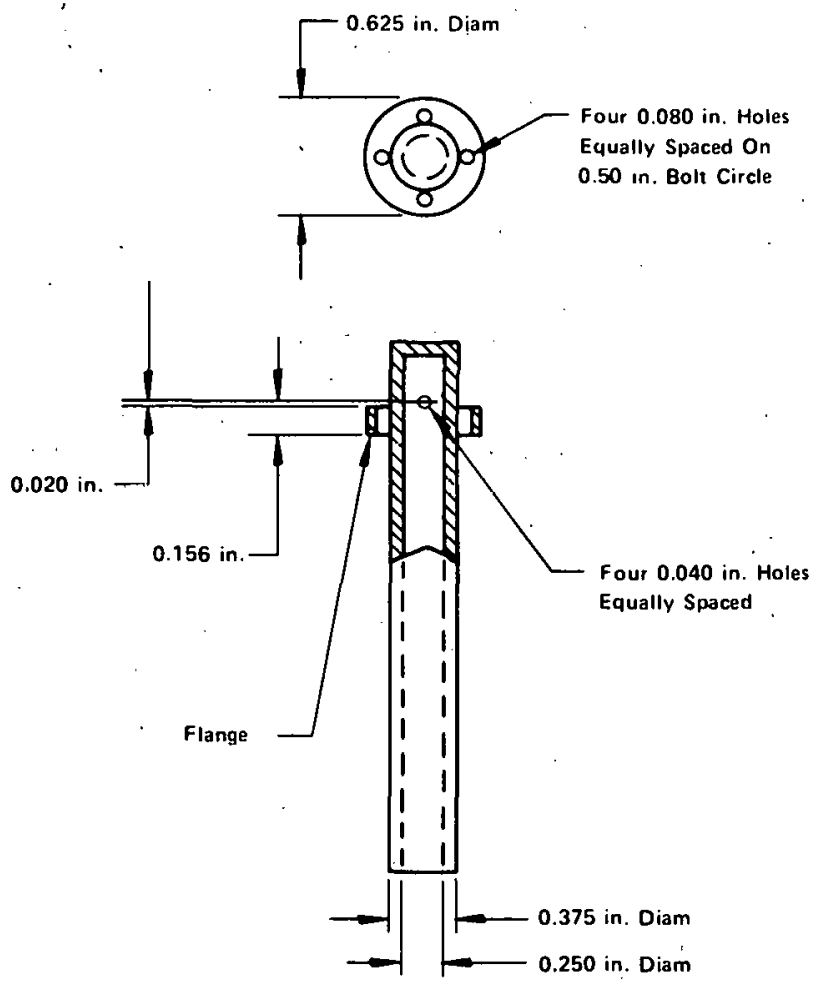

FIGURE 1 - Brass atomizing nozzle used for both generators.
"Leak Testing, HEPA Filter Installations" Section 6.2, DOP Smoke Generators.

Two simple, air-operated aerosol generators were built, one (MI) having one nozzle with four jets and the other (M6) having six nozzles with four jets each and control valves so that from one to six nozzles could be operated at any one time. Both generators have pressure gauges for all nozzles. The nozzle shown in Figure $l$ was used for both the $M l$ and M6 generators.

The Ml generator is shown in Figures 2-5. To increase the smoke generation, the prefilter material and one of the perforated metal plates were removed from the Ml generator after the first set of tests. The modified generator was designated MlM. The M6 generator is shown in Figure 6 .
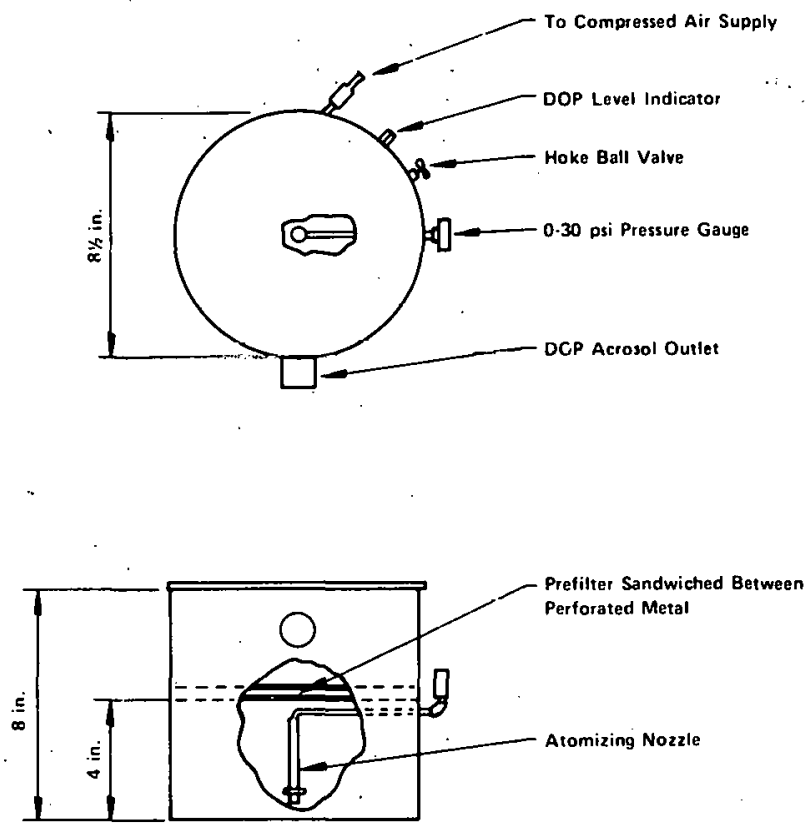

FIGURE 2 - One-nozzle generator $M 1$ before modification. 


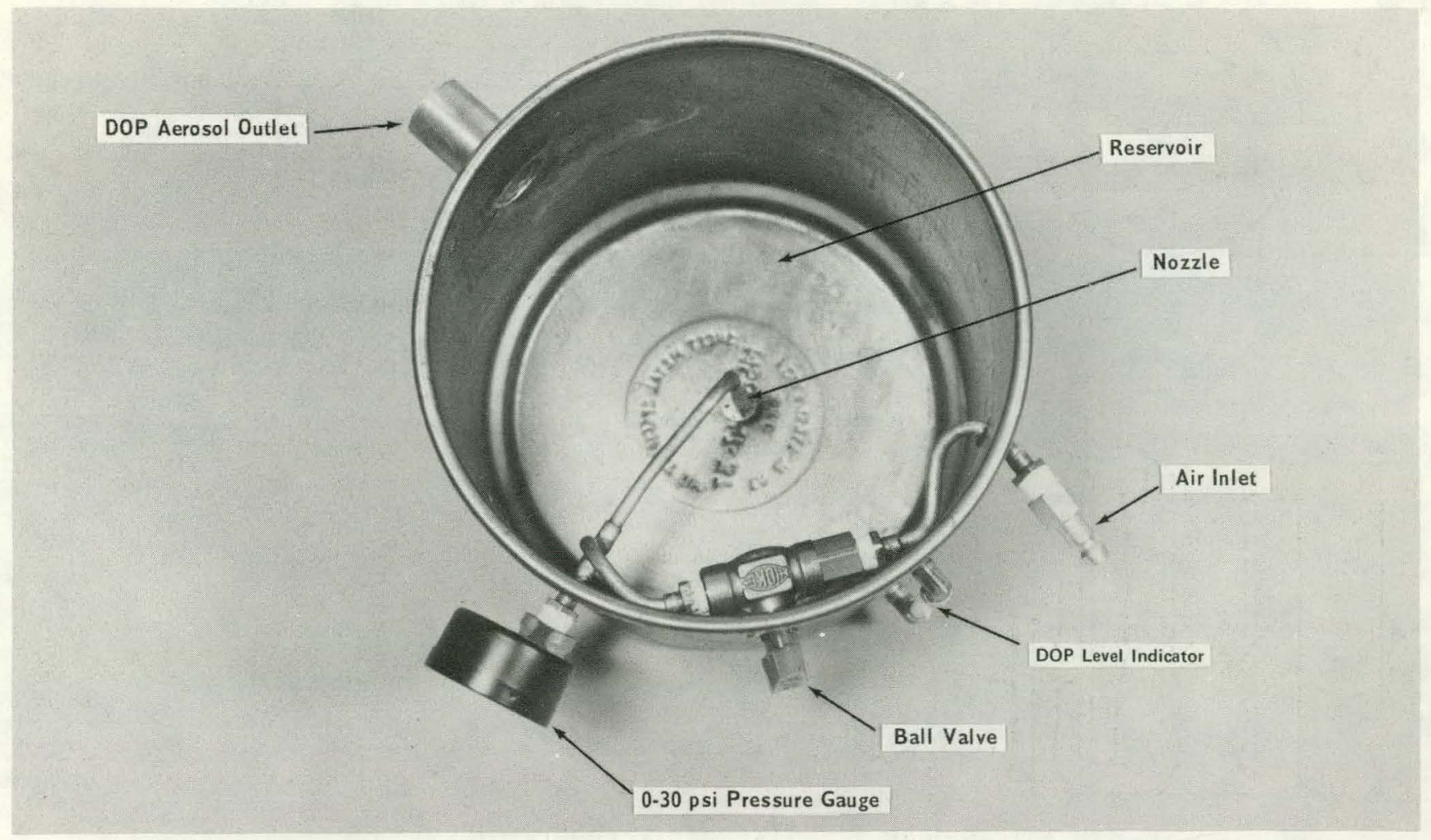

FIGURE 3 - One-nozzle DOP generator.

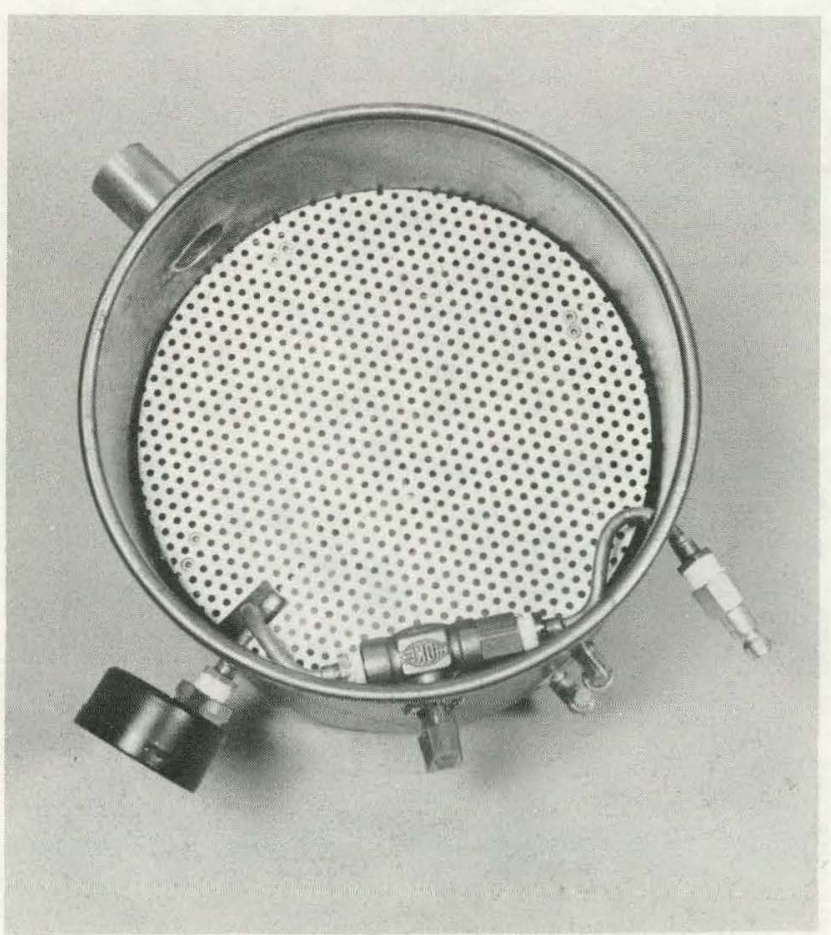

FIGURE 4 - One-nozzle DOP generator with perforated plate.

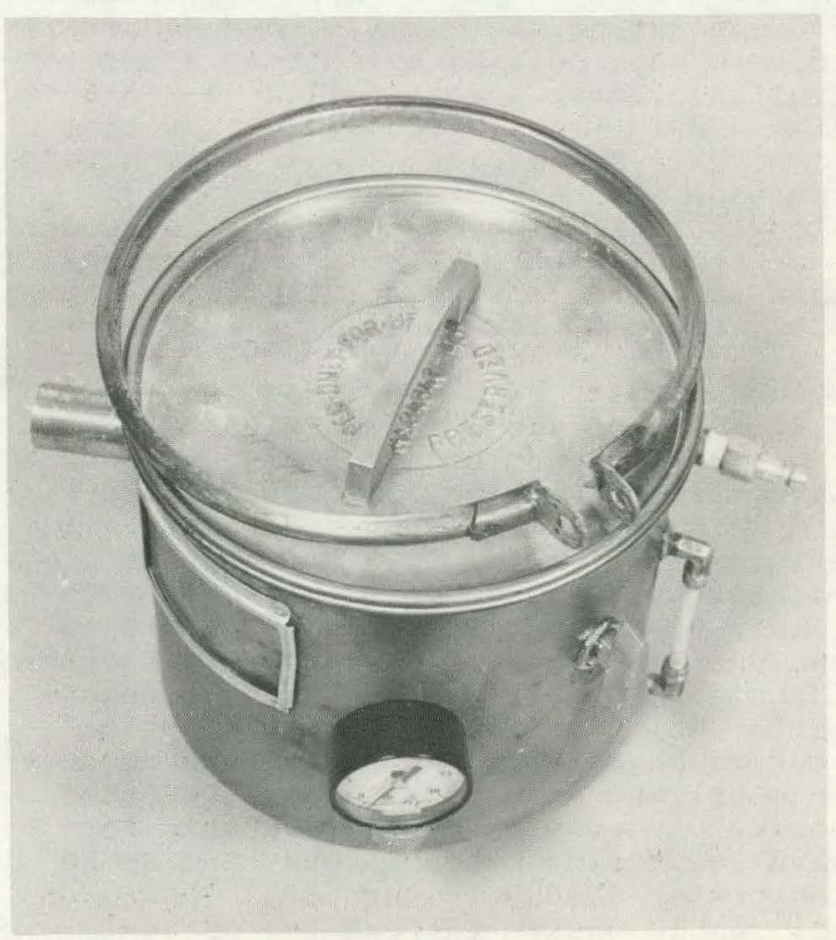

FIGURE 5 - One-nozzle DOP generator with lid. 

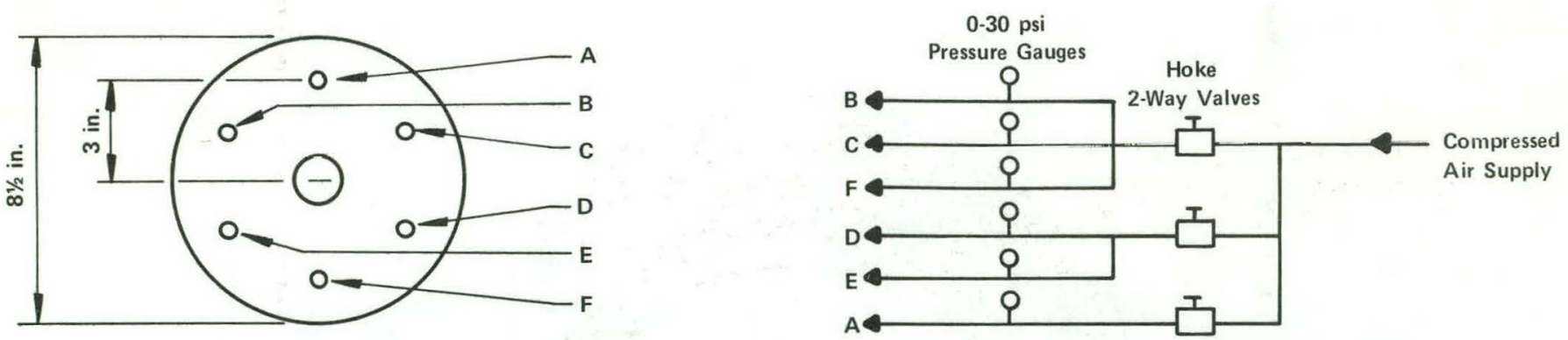

PIPING SCHEMATIC

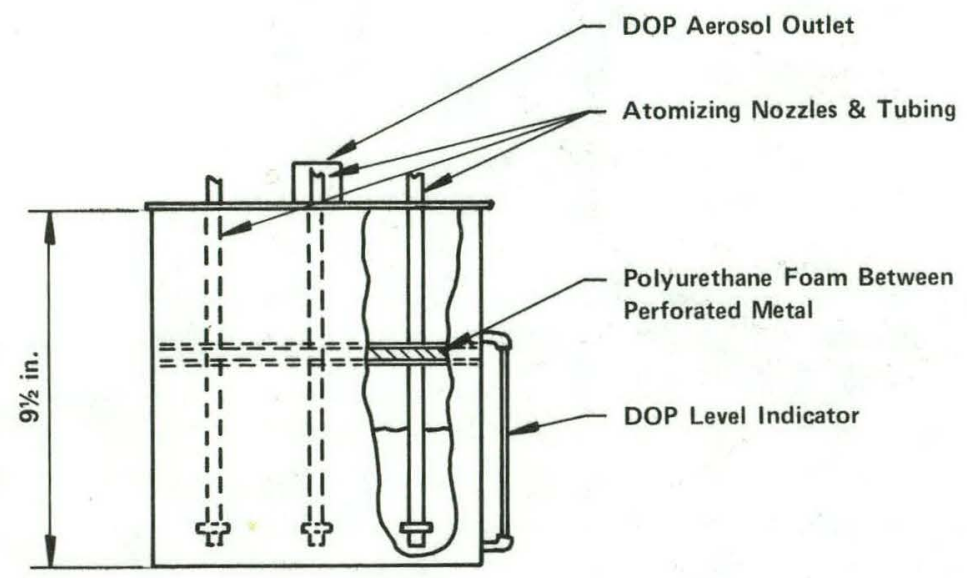

FIGURE 6 - Six-nozzle generator.

PERFORMANCE EVALUATIONS

The $24 \times 24 \times 5-7 / 8$ in. HEPA filter used for evaluating the Ml, MlM, and M6 generators was modified by cutting a section from the filter and installing a $3-3 / 8$ in. diam x 3 in. deep cardboard cup, bottom down, with RTV sealant. A 1/4-in. hole was made in the center of the cup to allow for sampling of the DOP aerosol concentration (Figure 7). This filter was then installed in the $24 \times 24$ in. plenum box (Figure 8) for testing HEPA filters.

We used two types of particle sensing devices. One was a Rayco PC200 particle counter which had been modified at Sandia Laboratories ${ }^{2}$ to include a dilution system (Figure 8) which, when activated, dilutes the sample going to the particle counter by a factor of 10, 100, or 1000 (i.e., 9, 99, or 999 parts clean air to one part sample air). The particle counter is able to differentiate the particulate matter which passes through the optical sensing chamber and provides both amount (number) and size ( $\mu \mathrm{m})$ data. The other device used was a Sinclair Phoenix Forward Scattering Aerosol, Dust and Smoke Photometer JM2000 (Figure 8). The aerosol sample passes through the optical sensing chamber of the photometer which measures the amount of light which has

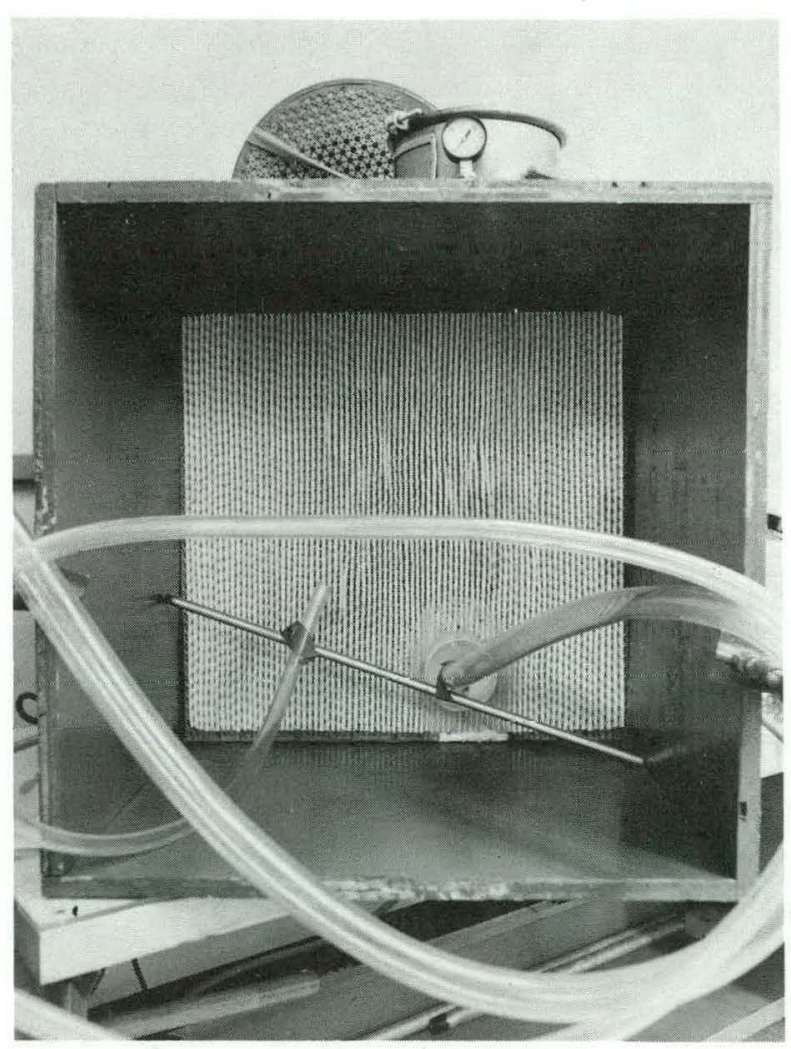

FIGURE 7 - Modified HEPA filter. 


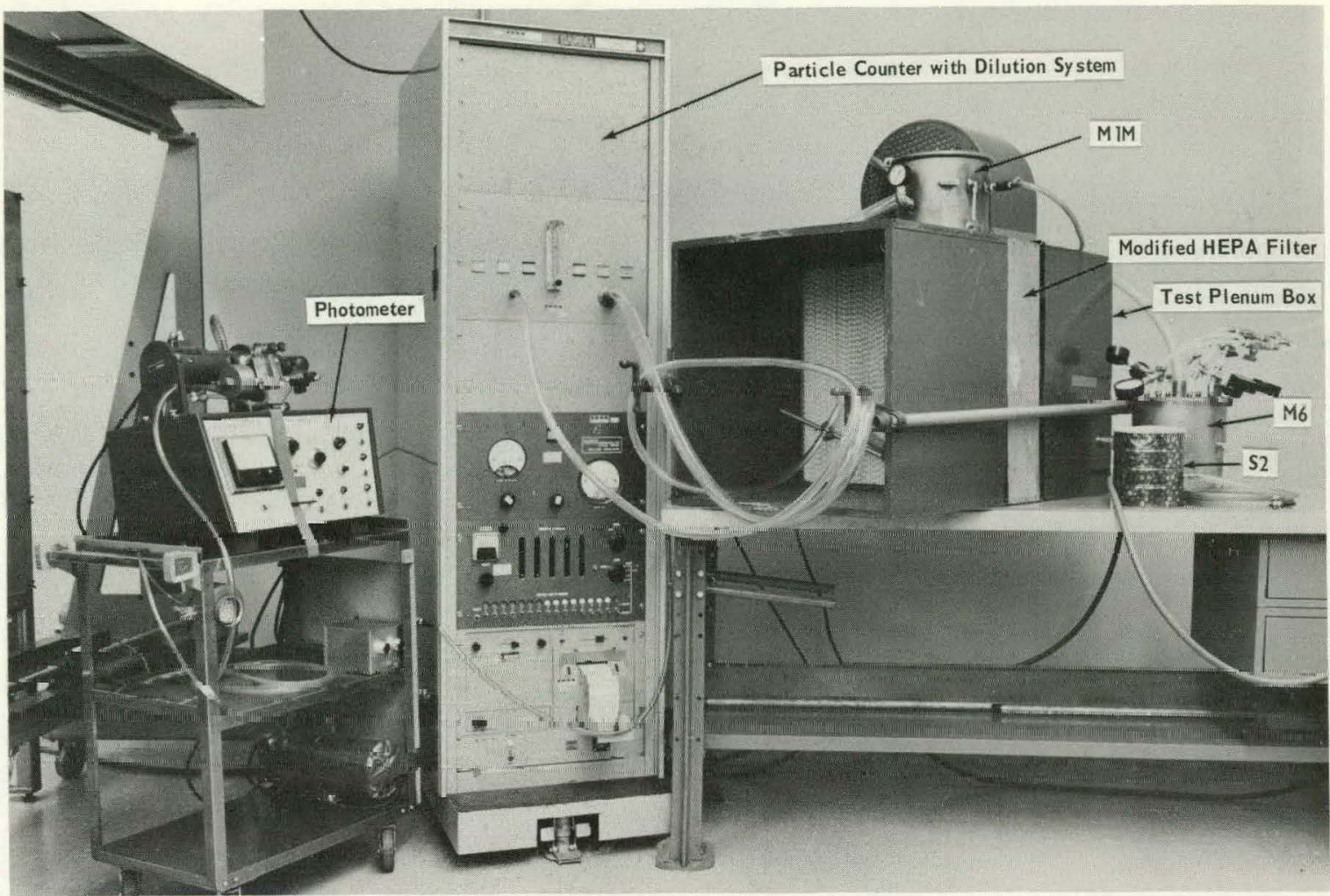

FIGURE 8 - Test equipment with DOP generator.

been scattered by the particulate matter. This measurement is a level of the mass concentration and can be evaluated on the graph provided with the photometer (see Figure 9).

Data were also tabulated from tests of a two-nozzle DOP Generator (S2) which had been built by Sandia Laboratories,

Manufacturing Research Division 2564.

The tests performed are listed in Table 1.

\section{RESULTS}

The results of the tests are tabulated in Tables $2-5$.

Table 2 shows the relationship between the Ml and MIM DOP generators. The DOP aerosol concentration increased approximately 35\% after the perforated plate and prefilter material were removed from Ml. However, even in the modified state, this generator does not approach the performance that was expected.

Table 3 shows the particle size distributions for all the DOP generators at 20 psi. As can be seen, the distribution is similar in most cases, with the highest concentration at the $0.3 \mu \mathrm{m}$ size level and decreasing as the particle size increases. However, in the M6-6 test the highest concentration occurred at the 0.5 and $0.6 \mu \mathrm{m}$ levels. In all cases, at about the $1.2 \mu \mathrm{m}$ level, the concentration began dropping drastically, and at $4.0 \mu \mathrm{m}$ and above no particles were detectable. These results were acceptable for our use.

Table 4 shows the DOP aerosol concentration as determined by the photometer. When the data from the MIM generator and the M6 generator with one nozzle open are compared (Figure 10), it can be seen that the M6 generator produces approximately $500 \%$ more DOP concentration. This increase is due to the large inlet tubing size of the M6 generator compared to that of the MlM generator.

The data from the M6 generator with two nozzles open compare very closely with those from the Sandia-built two-nozzle generator (Figure 11).

The data from the M6 generator tests with onc, two, three, and six nozzles open show that the DOP concentration levels go up as would be expected (Figure 12). These data correlate with the particle counter tests. 


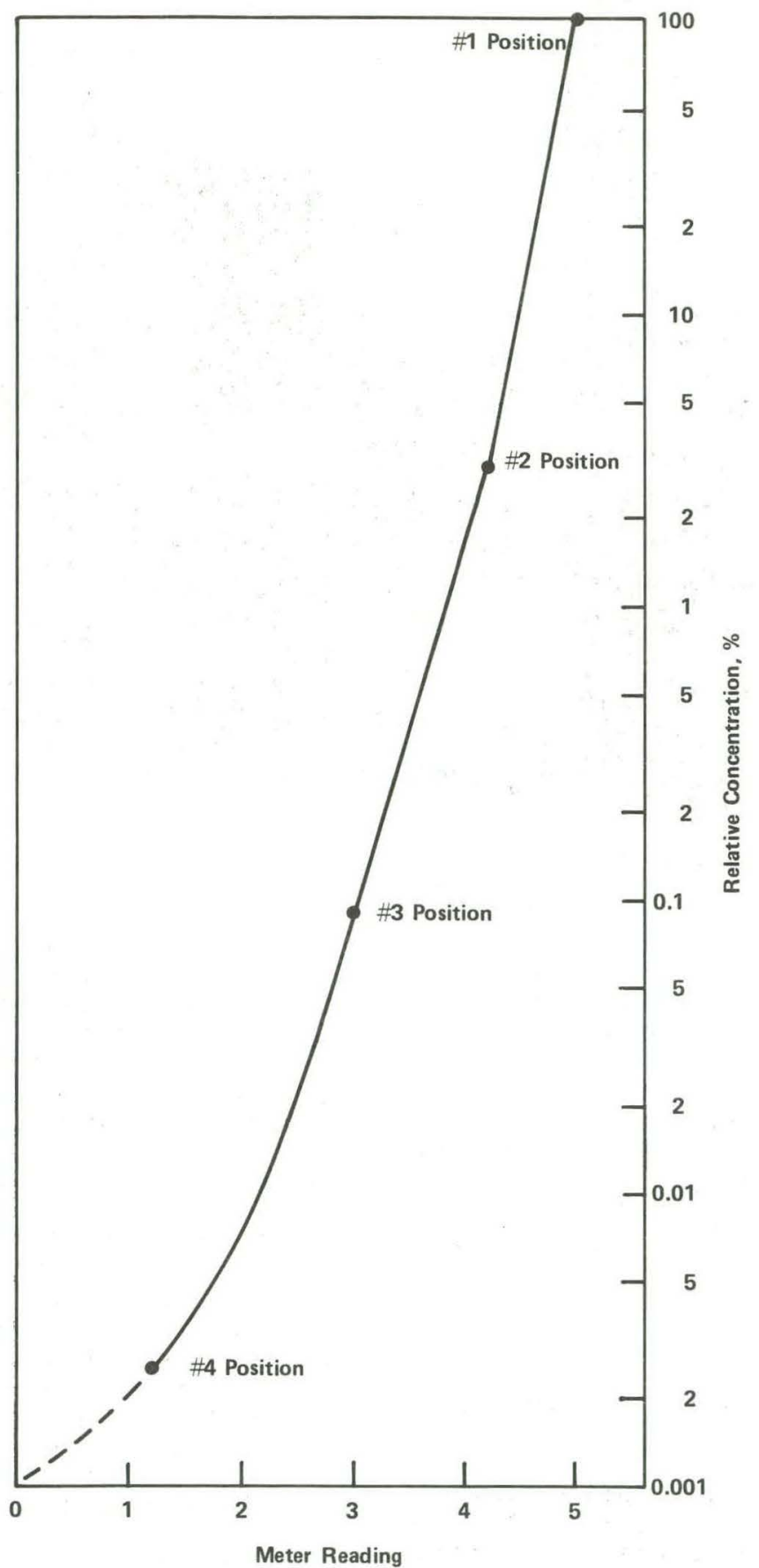

FIGURE 9 - Calibration of filter positions for aerosol photometer. 
Table 1

TFFTS PERFORMED TO DETERMINE DOP CONCENTRATION

\begin{tabular}{|c|c|c|c|c|c|}
\hline & Pressurre & & hera & rest & \\
\hline Test & (psi) & $\underline{M I}$ & $M I M$ & $\underline{M E}$ & $\underline{\mathrm{s}} 2$ \\
\hline $0.5 \mu \mathrm{m}$ and & 5 & $\mathrm{x}$ & $x$ & & $\mathrm{x}$ \\
\hline & 10 & $y$ & $\mathrm{x}$ & & $\mathrm{x}$ \\
\hline & 15 & $\mathrm{x}$ & $\mathrm{x}$ & & $\mathrm{x}$ \\
\hline & 20 & $x$ & $x$ & $x^{b}$ & $\mathrm{x}$ \\
\hline & 25 & $\mathrm{x}$ & $\mathrm{x}$ & & $\mathrm{x}$ \\
\hline & 30 & $\mathrm{x}$ & $\mathrm{x}$ & & \\
\hline $0.3 \mathrm{~mm}_{\mathrm{c}}^{\text {to }} 4.0$ & 20 & $\mathrm{x}$ & $\mathrm{x}$ & $x^{d}$ & $\mathrm{x}$ \\
\hline Photometer & 5 & & $\mathrm{x}$ & $x^{e}$ & $\mathrm{x}$ \\
\hline & 1.0 & & $\mathrm{x}$ & $x^{e}$ & $\mathrm{x}$ \\
\hline & 15 & & $\mathrm{x}$ & $x^{e}$ & $\mathrm{x}$ \\
\hline & 20 & & $\mathrm{x}$ & $x^{e}$ & $\mathrm{x}$ \\
\hline & 25 & & $\mathrm{X}$ & $x^{e}$ & $\mathrm{X}$ \\
\hline & 30 & & $\mathrm{x}$ & $x^{e}$ & $x$ \\
\hline
\end{tabular}

aparticles/ft ${ }^{3}$ of air/min equivalent.

bested with one, two, three, four, five, and six nozzles open.

${ }^{c} 0.3$ to $4.0 \mu \mathrm{m}$ particle distribution was tested per $\mathrm{ft}^{2}$ of air per min equivalent.

Tested with one, three, and six nozzles open.

erested with one, two, three, and six nozzles open.

Table 2

DOP CONCENTRATIONS PRODUCED BY GENERATORS

$M I$ and MIM AT DIFFERENT PRESSURES

Pressure

(psi)

5

10

15

20

25

30

DOP Concentrationa

from Cenerators

MI MIM

$0.4 \times 10^{7} \quad 0: 58^{7} \times 10^{7}$

$1.1 \times 10^{7}$

$1.44 \times 10^{7}$

$1.5 \times 10^{7}$

$1.92 \times 10^{7}$

$1.8 \times 10^{7}$

$2.35 \times 10^{7}$

$2.1 \times 10^{7}$

$2.69 \times 10^{7}$

$2.3 \times 10^{7}$

$2.98 \times 10^{7}$

A Rumided off avcrage number nf particles $0.5 \mu \mathrm{m}$ and above per $\mathrm{ft}^{3}$ of air per min over a 10 -min period usiny the particle counter with the dilution set on $10^{-2}$. 
Table 3

PARTICLE SÍ́ E CONCENTRATION DISTRIBUTION TESTS ${ }^{a}$

\section{Particle \\ Size}

$(\mu \mathrm{m})$

\section{3}

0.4

0.5

0.6

0.8

1. 2

1.5

2.0

3.0

$4.0^{e}$

\section{M.}

$3.1 \times 10^{7}$

$2.5 \times 10^{7}$

$1.9 \times 10^{7}$

$1.4 \times 10^{7}$

$1.0 \times 10^{7}$

$2.0 \times 10^{6}$

$6.0 \times 10^{5}$

$8.0 \times 10^{4}$

$1.0 \times 10^{4}$

0 $\frac{\text { Concentration Produced }}{M 6-1 \mathrm{~b}}$

\begin{abstract}
$3.7 \times 10^{7}$
\end{abstract}
$3.1 \times 10^{7}$

$2.5 \times 10^{7}$

$1.8 \times 10^{7}$

$1.2 \times 10^{7}$

$2.4 \times 10^{6}$

$5.5 \times 10^{5}$

$8.2 \times 10^{4}$

$1.0 \times 10^{4}$

0

\begin{abstract}
$19 \times 10^{7}$
$14 \times 10^{7}$

$10 \times 10^{7}$

$6.5 \times 10^{7}$

$3.5 \times 10^{7}$

$4.9 \times 10^{6}$

$1.0 \times 10^{6}$

$1.0 \times 10^{5}$

$1.0 \times 10^{4}$

0
\end{abstract}

M6-3c

$35 \times 10^{7}$

$33 \times 10^{7}$

$28 \times 10^{7}$

$22 \times 10^{7}$

$14 \times 10^{7}$

$26 \times 10^{6}$

$7.0 \times 10^{6}$

$9.6 \times 10^{5}$

$7.2 \times 10^{4}$

$\underline{M 6-6}{ }^{d}$

$26 \times 10^{7}$

$\underline{52}$

${ }^{a}$ All readings taken with 20 psi at the nozzles.

${ }^{\mathrm{b}}$ 6 generator with one nozzle open.

${ }^{c_{M 6}}$ generator with three nozzles open.

${ }^{M 6}$ generator with six nozzles open.

$\mathrm{e}_{4.0} \mathrm{\mu m}$ and above no particles were detected.

$30 \times 10^{7}$

$34 \times 10^{7}$

$34 \times 10^{7}$

$30 \times 10^{7}$

$97 \times 10^{6}$

$33 \times 10^{6}$

$64 \times 10^{5}$

$50 \times 10^{4}$

0
$32 \times .10^{7}$

$27 \times 10^{7}$

$21 \times 10^{7}$

$15 \times 10^{7}$

$8.7 \times 10^{7}$

14. $\times 10^{6}$

$3.5 \times 10^{6}$

$4.5 \times 10^{5}$

$3.6 \times 10^{4}$

0 
Table 4

DOP AEROSOL CONCENTRATION PRODUCED AS TESTED BY PHOTOMETER ${ }^{\mathrm{a}}$

Relative Concentration ( $\left.\frac{g}{b}\right)$ Produced by

\begin{tabular}{|c|c|c|c|c|c|c|}
\hline \multirow{2}{*}{$\begin{array}{c}\text { Pressure } \\
\text { (psi) } \\
\end{array}$} & & & \multicolumn{4}{|c|}{ Generators } \\
\hline & $\overline{\mathrm{s2}}$ & M1M & $\mathrm{MG}-1^{\mathrm{D}}$ & $\mathrm{MG}-2^{\mathrm{C}}$ & $M \bar{c}-3^{d}$ & $\mathrm{M} 6-\overline{6}^{\circ}$ \\
\hline 5 & 1.3 & 0.28 & 1.6 & 2.8 & 3 & 7 \\
\hline 10 & 6.8 & 0,7 & 4.7 & 8.0 & 13 & 30 \\
\hline 15 & 12.0 & 1.0 & 7.1 & 14.0 & 25 & 46 \\
\hline $20^{\circ}$ & 15.0 & 1.3 & 11.0 & 20.0 & 31 & 54 \\
\hline 25 & 19.0 & 1.5 & 12.1 & 22.0 & 38 & 62 \\
\hline 30 & 21 & 1.52 & 12.0 & 26.0 & 40 & 70 \\
\hline
\end{tabular}

${ }^{a}$ Relative concentration based on Figure 9 and meter readings.

$\mathrm{b}_{\mathrm{M} 6}$ generator with. one nozzle open.

cM6 generator with two nozzles open.

$\mathrm{d}_{\mathrm{M} 6}$ generator with three nozzles open.

$\mathrm{e}_{\mathrm{M} 6}$ generator with six nozzles open.

Table 5

DOP CONCENTRATIONS FOR SIX-NOZZLE GENERATOR ${ }^{a}$

WITH DILUTION SYSTEM SET ON $10^{-2}$

\begin{tabular}{ccc}
$\vdots$ & $:$ & \\
Nozzles & Open \\
\hline & 1 & \\
& 2 & \\
$:$ & 3 & \\
$:$ & 4 & \\
$\vdots$ & 5 \\
& 6
\end{tabular}

Average 10-min

Concentrationb

WITH DILUTION SYSTEM SET ON $10^{-3}$

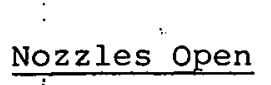

1

2

3

$\therefore \quad 4$

5

6
$8.6 \times 10^{7}$

$17.0 \times 10^{7}$.

$24.5 \times 10^{7}$

$29.9 \times 10^{7}$

$33.3 \times 10^{7}$

$34.0 \times 10^{7}$

Average 10-min

Concentration

$5.6 \times 10^{7}$

1.1. $\times 10^{7}$

$16.6 \times 10^{7}$

$23 \times 10^{7}$

$30 \times 10^{7}$

$38 \times 10^{7}$

${ }^{a}$ All readings taken. with $20 \mathrm{psi}$ to the nozzles, $0.5 \mu \mathrm{m} / \mathrm{ft}^{3}$ of air/min and above using the particle counter.

$\mathrm{b}_{\text {Particles } / \mathrm{ft}^{3} \text {. }}$ 


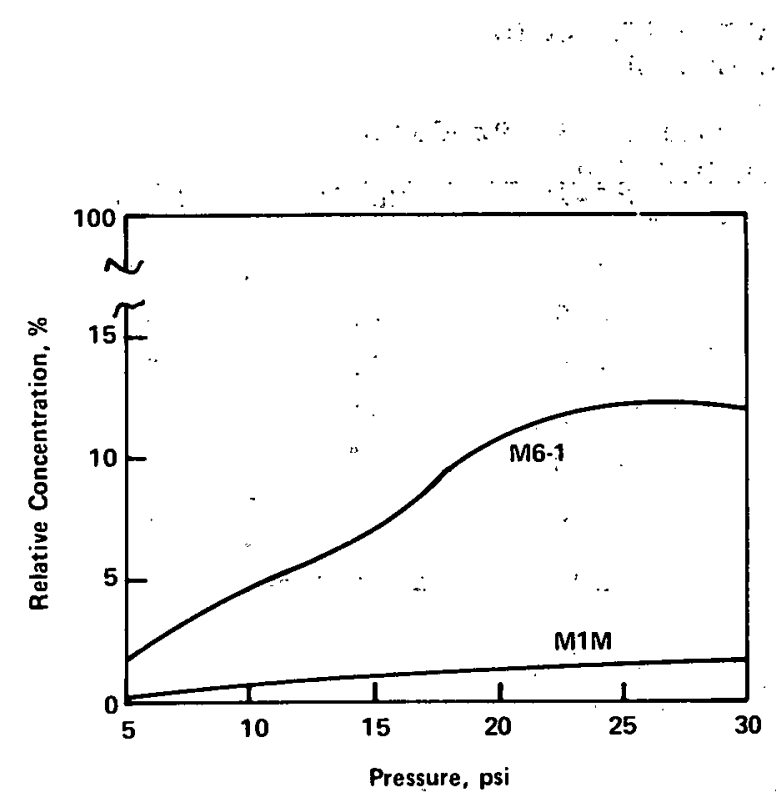

FIGURE 10 - Relative concentrations produced by the MlM and $M \ddot{6}$. (with one nozile open) at different pressures.

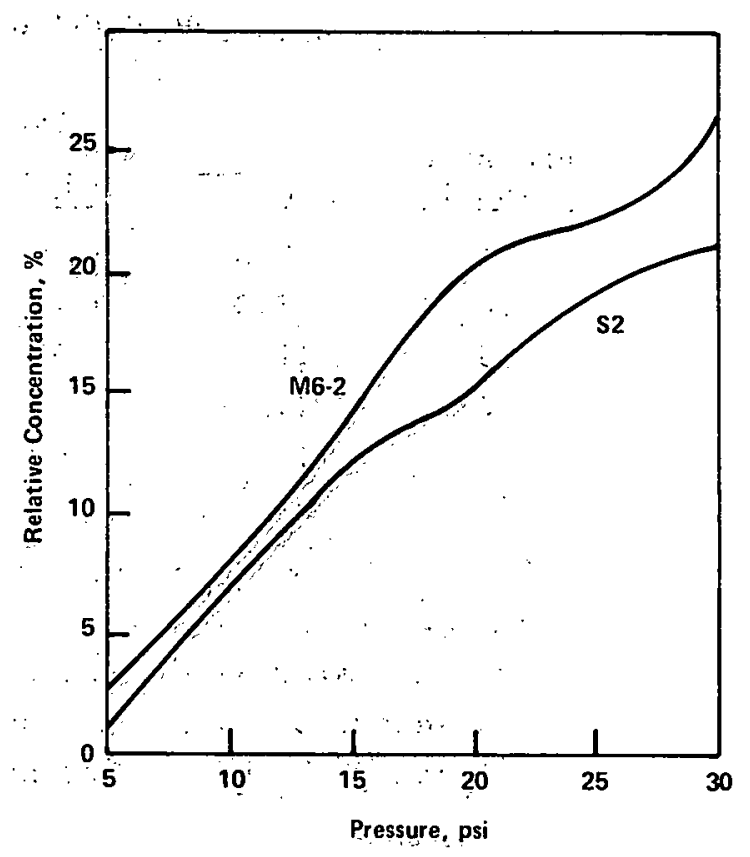

FIGURE Il - Relative concentration produced by the $s 2$ and M6 (with two nozzles open) generators at different pressures.

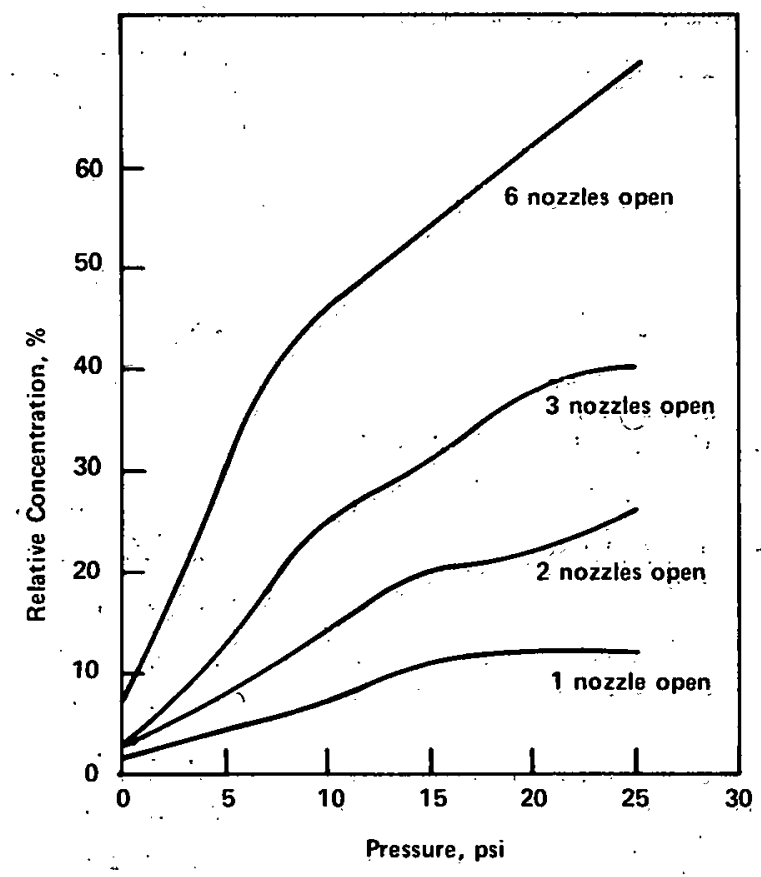

FIGURE:I2 - Relative concentration produced'at different pressures' by the $M 6 \cdot$ generator with one; two, three, and six nozzles open. 
Table 5 shows that the M6 generator does produce more aerosol concentration as the nozzles are added. The $10^{-2}$ and the $10^{-3}$ ranges did not exactly agree (see Figure 13); however, the generator does produce at approximately the amount that would be expected. (It is believed that in the $10^{-2}$ range with five and six nozzles open, the particle counter was approaching its saturation point.)

\section{CONCLUSIONS}

The six-nozzle DOP generator performed reasonably well for the anticipated usage that it will receive at Mound Laboratory. We were pleased with the particle size distribution data which showed the majority of the dispensed DOP aerosol to be in the 0.3 to $0.8 \mu \mathrm{m}$ range for the tests run.

The one-nozzle DOF generator did not perform as expected because the $1 / 8$ in. nominal copper tubing from the inlet to the nozzle was too small. However, it can be used to supply the DOP aerosol concentration to our new automated HEPA Filter Scanner Tester (Figure 14).

This preliminary development effort indicates that a three-nozzle DOP generator with $1 / 4$ to $3 / 8-i n$. i.d. tubing would be the optimum design for our use when clean air modules ${ }^{1}$ are tested. Some thought also has been given to the use of a gross particle trap reservoir after the aerosol outlet and to changing the nozzle design by opening up the jet size. ${ }^{3}$

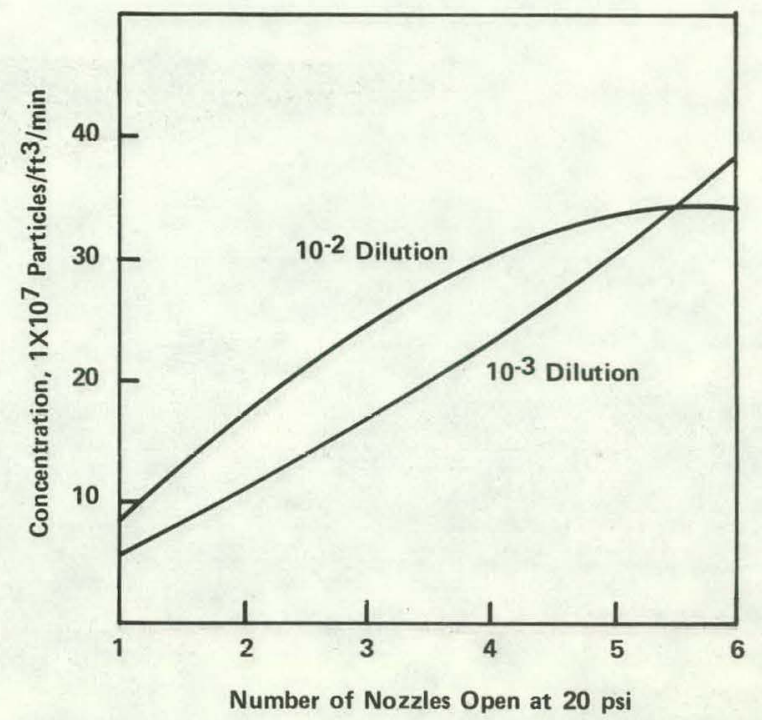

FIGURE 13 - Particle concentration produced by the $M 6$ generator as determined by the particle counter at $10^{-2}$ and $10^{-3}$ dilutions.

\section{ACKNOWLEDGMENTS}

I am grateful to R. Earley of Miami University and T. K. Ferguson, R. E. Huss, and R. L. Shaffer for their encouragement and support.

REFERENCES

1. Federal Standard 209B.

2. W. E. Neitzel, Development of a Precision Numerical Dilution System for Aerosols, SC-PR-67-367 (september, 1967), pp. 10-14.

3. W. H. Echols and J. A. Young, Studies of Portable Air Operated Aerosol Generators, NRL-5929 (July 26, 1963). 


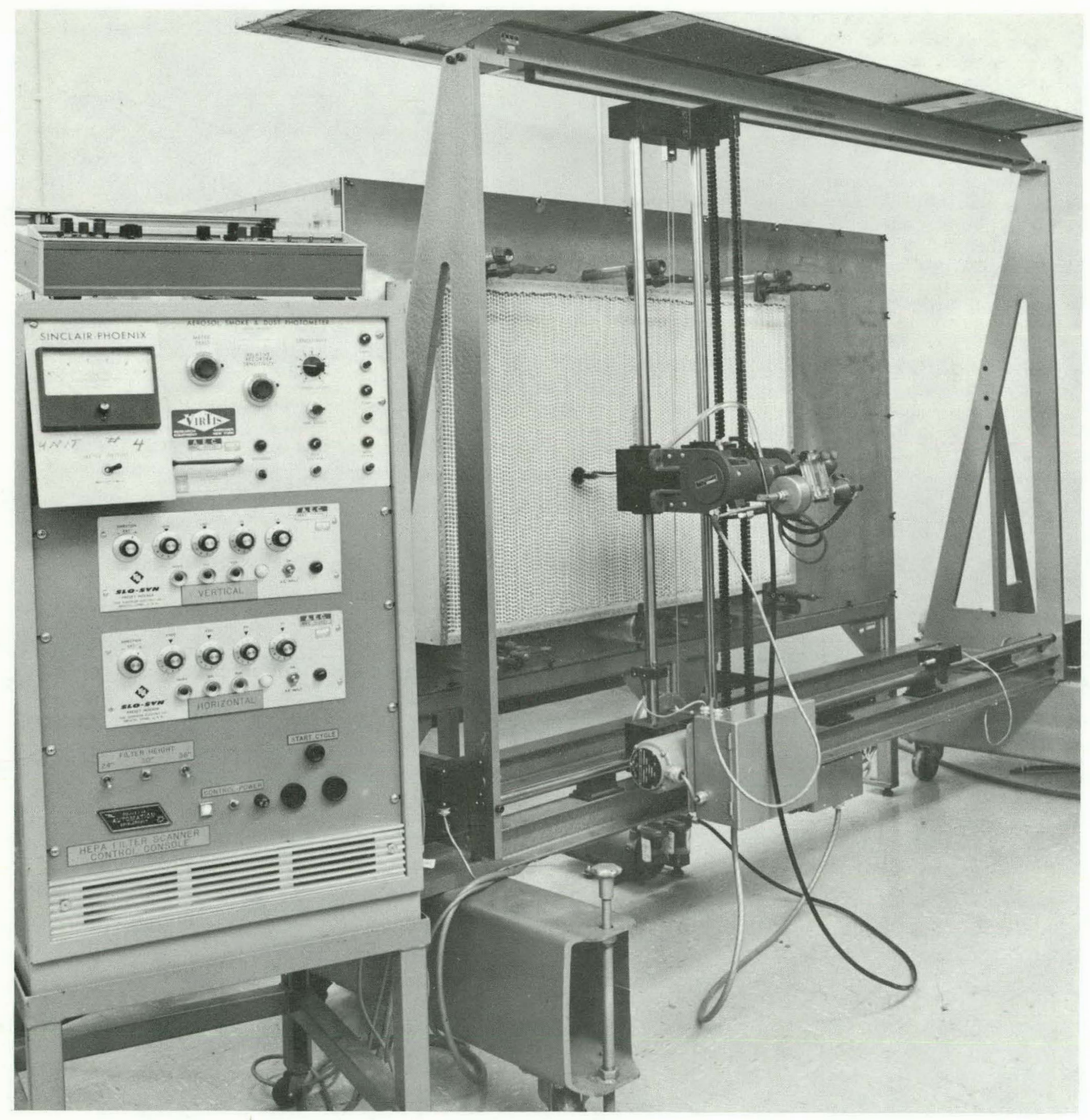

FIGURE 14 - HEPA Filter SCanner Tester. 
Hot DOP generators are used to detect leaks in air filtration systems. Each generator requires $110 \mathrm{~V}$ ac and a source of compressed nitrogen. An aerosol of consistent particle size distribution is created by discharging a regulated quantity of DOP liquid into a heated area. The DOP is vaporized and reconstituted. into a polydispersed aerosol by a small amount of nitrogen.

Cold DOP generators are used to detect leaks in air filtration systems. All that is required to operate is a source of clean compressed air. Based on the Laskin nozzle type apparatus, it creates a liquid aerosol concentration of consistent particle size distribution by sllediluy the DOP liquid with ai,r. 
DISTPRIBUTION

\section{External}

TIC, UC-38 (169). .

Consultants

C. F. Curtiss

University of Wisconsin

C. F. Eck

Miamisburg, Ohio

D. F. Griffing

Mịami University

J. H. Leonard

University of Kentucky

R. E. Miers

Ft. Wayne, Indiana

W. E. Moddeman

University of Dayton Research Institute

G. W. Powell

Ohio State University

A. Shapiro

University of Cincinnati

H. F. Swift

University of Dayton Research Institute

D. White

University of Pennyslvania

R. D. Earley, Miami University, Middletown; O.

D. W. Young, Miami University, Middletown, 0 .

Dr. C. L. Wright, Jr., Frontier Enterprises, Inc., Albuquerque, NM

John Quante, Flanders Filters, Inc.,

washington, NC

Dr. J. K. Thompson, U.S. Navy Research Laborątory

R. K. Flitcraft, MRC

H. W. Mattson, Monsarto Co.

\section{Internal}

J. E. Bradley

C. F. Draut

R. D. Evans

L. G. Fauble

T. K. Ferguson

c. W. Huntington

R. L. Huss

J. R. MCClain

R. I. Mielke (12)

R. L. Shaffer

Publications

Library (15) 